\title{
BIM 기반의 준설매립전용 Library Browser 개발 Developing Object Library Browser for Reclamation Based BIM
}

\author{
이 동 윤 $^{\dagger}$ 이 준 호 $^{1)} \cdot$ 이 상 웅 ${ }^{1)} \cdot$ 최 차 석 ${ }^{11} \cdot$ 구 본 효 ${ }^{2}$ \\ Dongyun Lee $\cdot$ Junho Lee $\cdot$ Sangwoong Lee $\cdot$ Chaseok Choi $\cdot$ Bonhyo Gu
}

Received: December 15 ${ }^{\text {th }}, 2013$; Revised: December 26 $6^{\text {th }}, 2013$; Accepted: January $28^{\text {th }}, 2014$

\begin{abstract}
This study has been conducted to building a library intended for structures considered in the design of reclamation for design automation and developing browser for integrated management system. The library has been developed using a parametric modeling method capable of changing section shape, also classifying standard crossing and family library, has been developed according to the working environment. Classified library by the characteristics manages objects and working modeling on based BIM has been developed browser using the $\mathrm{C}$ \# program for objects to use conveniently. By interworking between developed Browser and 3D Autocad based BIM, it is possible to use easily at design drafting, calculating quantities, developing a new library, and managing a library. The browser using effectively exclusive library to reclamation is developed in this study.
\end{abstract}

Keywords : BIM, Reclamation, Library, Browser, 3D Autocad

요 지 : 본 연구에서는 준설매립분야의 설계자동화를 위하여 준설토 투기장 설계 시 고려되는 상부 및 하부 구조물을 대상으로 Library를 구축하고, 이를 통합·관리할 수 있는 브라우저를 개발하였다. 개발 Library는 주요 단면제원을 변수화하여 형상의 가변성 확보가 가능한 파라메트릭 모델링 방법을 이용하여 작성하였으며, 작업환경에 맞게 표준횡단 및 패밀리 Library로 구분하여 작성하 였다. 작성된 Library를 특성별로 구분하여 객체를 관리하고 $\mathrm{BIM}$ 기반 모델링 작업 시 객체의 적용이 간편하도록 C\# 언어를 이용하 여 브라우저를 개발하였다. 개발된 브라우저를 BIM 기반의 3차원 캐드 프로그램에 연동함으로써 간편하게 3 차원 모델링, 도면작성 및 물량산출이 가능하고 신규 Library의 작성 및 관리 또한 가능하다.

주요어 : 건설정보모델링, 준설매립, 라이브러리, 브라우저, 3 차원 캐드

\section{1. 서 론}

초기 건축분야에서 시작된 BIM(Building Information Modeling) 기술은 최근 건설산업의 대형화 및 복잡화로 인해 토목분야 의 정보화 시공 및 유지관리를 위한 시스템으로 그 적용성 이 증가하고 있는 실정이다. BIM 기술을 설계 및 시공단계 에 도입함으로써 구조물, 부재, 공종 간 간섭검토 및 시공성 검토를 통하여 공사 중 위험요인을 사전에 감지하고, 설계 오류에 대한 사전분석이 가능하여 건설프로젝트의 효율성 증가, 비용절감 및 공기단축의 효과가 있어 그 사용성은 더 욱 증가할 것으로 평가되고 있다. 그러나 토목분야에 이러 한 $\mathrm{BIM}$ 기술이 활성화되기 위해서는 분야별로 적용되고 있 는 구조물의 특성, 각종 지반개량공법 및 시공 장비의 특성 등을 반영할 수 있는 다양하고 적절한 Library의 구축이 필 수적으로 선행되어야 한다.

건축분야는 이미 $\mathrm{BIM}$ 기반구축이 활발히 진행되고 있으
며, 비교적 규격화된 재료들을 이용하기 때문에 BIM 관련 소프트웨어에 관련 Library들이 많이 포함되어 있으며, 또 한 지속적인 Library의 개발 및 업그레이드가 진행되고 있 는 실정이다. 토목분야의 BIM 기반구축을 위하여 Kang et al.(2011)은 토목공사 기획 및 설계단계의 BIM 적용방안에 대하여 연구성과를 제시한 바 있으며, Jun \& Yun(2011)은 시공계획 지원을 위한 시공객체에 대하여 형상, 규격 및 성 능을 고려한 Library 개발 연구를 수행하였다. 또한 Han \& $\operatorname{Nam}(2011)$ 은 토목분야 견적시스템에 대하여 Library를 이 용한 견적 자동화 시스템에 관한 연구를 수행하였다.

이렇듯 토목분야의 BIM 기반구축을 위해서는 토목구조 물, 공정 및 견적 등을 간편하게 모델링 할 수 있는 Library 의 구축이 필수적이지만 준설매립분야의 경우 현장조건별 로 불연속적이고 비정형화된 구조물이 일반적으로 사용됨 으로써 전용 Library의 구축이 어려운 실정이다. 따라서 현 장조건별 비규격화된 상부 및 하부구조물을 적용하는 준설

† Geotechnical Engineering, Hang-Do Engineering (Corresponding Author : yun@hangdoeng.co.kr)

1) Geotechnical Engineering, Hang-Do Engineering

2) Head of Research Center, Hang-Do Engineering 
매립분야에서는 주요 단면 제원을 변수로 하여 구조물의 가변성을 확보할 수 있는 파라메트릭(Parametric) Library 의 구축이 필수적이다. 이러한 파라메트릭 기술기반의 국내 연구성과로 Hong et al.(2011)이 철근콘크리트 구조물의 기 둥부재 자동배근 시스템 구축에 대한 연구를 수행한 바 있 고, Han et al.(2011)은 파라메트릭 모델링에 의한 토목구조 물 모듈 Library 구축에 관한 기초적인 연구를 수행한 바 있 으나, 준설매립 분야에 적용 가능한 Library 구축에 관한 연 구는 수행된 바가 없는 실정이다.

이에 본 연구에서는 준설매립분야의 상부 및 하부구조물을 대상으로 가변성 확보가 용이한 전용 파라메트릭 Library를 구 축하였으며, 개발된 Library의 통합관리가 용이하고 BIM 기 반의 $3 \mathrm{D}-\mathrm{CAD}$ 와 연동 가능한 Library Browser를 개발하였다.

\section{2. 준설매립 전웡 Library 개발}

본 연구에서는 $\mathrm{BIM}$ 기반의 3D-CAD 상용프로그램인 Autodesk Civil 3D를 이용하여 파라메트릭 Library를 작성 하였다. 작성된 Library는 크게 표준횡단 Library 및 Family Library로 구분된다.

\section{1 표준횡단 Library}

표준횡단 Library는 기초사석, 피복석, 필터사석, 상치콘 크리트 등과 같이 수평 방향으로 연속적인 $3 \mathrm{D}$ 객체 Library

\section{(a) Creating flow chart}

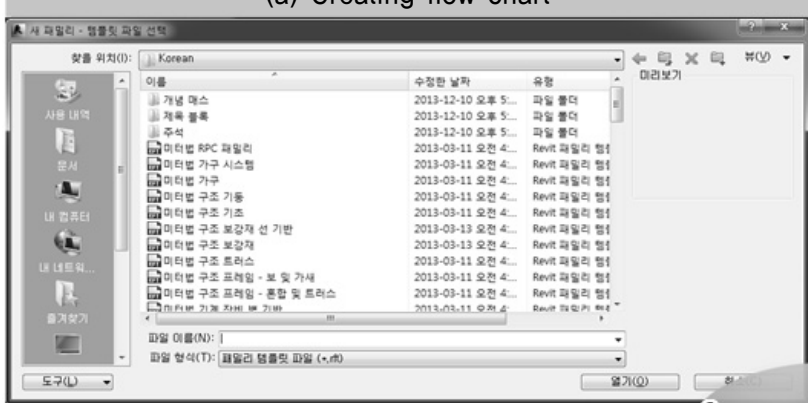

Save as * PKT file

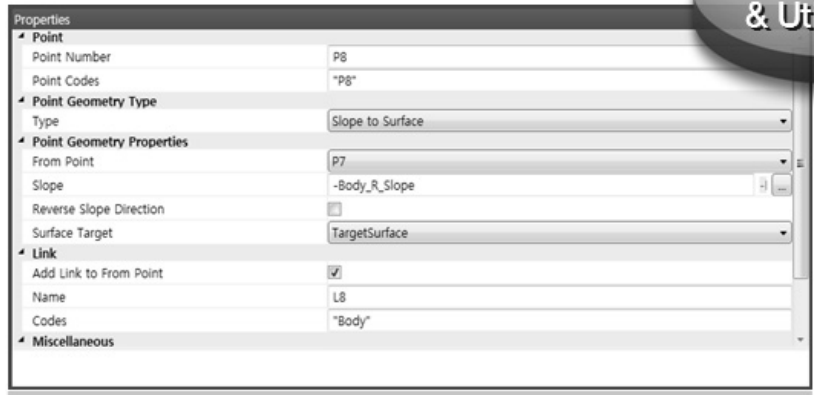

(c) Define position of point \& line using the parameter name
를 생성하는 것으로써 Civil 3D 상에서 사용되며, 3D 코리 더(Corridor) 모형의 기본 구조를 형성하는데 사용된다.

현재 Civil 3D에서는 Fig. 1과 같이 프로그램 내의 도구 팔레트에 도로, 교량 등의 기본적인 Library를 제공하고 있 지만, 설계 시에 사용자가 필요로 하는 Library를 모두 제공 해 줄 수는 없기 때문에 제공되는 Library 이외의 형상은 사 용자가 직접 모델링하여 사용하여야 한다.

표준횡단 Library를 생성하는 방법은 크게 두 가지로 구 분된다. 첫 번째 방법은 Civil 3D 내에서 표준횡단 Library

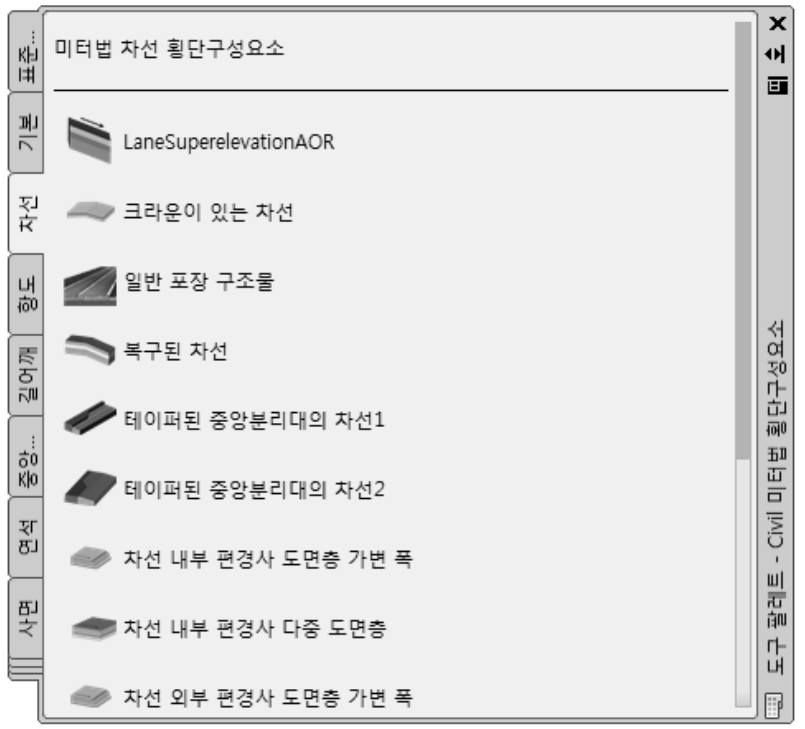

Fig. 1. Library Pallet

Fig. 2. Process of creating library using Subassembly Composer 
형상을 폴리라인으로 작성하는 방법이다. 이 방법을 이용할 시 Library 생성은 간편하나 도구 팔레트에 추가할 수 없어 다른 프로젝트에서의 재활용이 어려운 단점이 있다. 또한 형상의 정의만 가능할 뿐 파라메트릭 요소를 사용한 형상치 수의 조정이 불가능하므로 계획된 구조물의 형상이 변경될 때마다 새로운 Library를 작성하여야 하는 한계성을 가지고 있다.

두 번째 방법은 서브어셈블리 컴포저(Subassembly Composer) 를 이용하는 방법이다. 서브어셈블리 컴포저는 Civil 3D 설치 시 옵션으로써 제공되는 표준횡단 Library 생성 프로 그램이다. 서브어셈블리 컴포저는 Fig. 2와 같이 Tool Box 의 Workflow 도구를 이용하여 작성하고자 하는 Library의 Flowchart를 작성한 후 Geometry, Auxiliary, Miscellaneous 등의 도구를 활용하여 Library 형상에 대한 점과 선을 정의 한다. Input/Output Parameters에서 변수명 및 변수값을 정의 하고, Properties 창에서 변수명을 활용하여 점 및 선의 위치 를 정의한 후 각 점 및 선에 대한 코드를 부여한다.

이렇게 작성된 표준횡단 Library는 “*.pkt” 파일 형태로 저장되며, 저장된 파일을 Civil $3 \mathrm{D}$ 의 도구 팔레트에 추가함 으로써 프로젝트 변경 시에도 반복적으로 사용 가능하다. 또한 폴리라인을 사용하여 생성한 Library와 달리 사용자가 Input/Output Parameters에서 정의한 변수값을 이용하여 구 조물의 단면변화에 따른 형상 및 형상치수의 변경이 용이한 장점을 가진다.

\subsection{Family Library}

불연속적인 개별 Solid 객체 특성을 가지고 있는 케이슨 및 콘크리트 블록 등의 상부구조물과 수직 방향으로 시공되 는 $\mathrm{DCM}, \mathrm{SCP}$ 및 고압분사 등의 기초구조물은 표준횡단 Library로 작성이 불가능하기 때문에, 이러한 객체는 Revit 프로그램의 Family Library 작성을 통해 Solid 객체로 생성 하여야만 한다.

Revit 실행 후 Family 작성을 위한 템플릿 파일 선택창에 서 사용자가 Library 특성에 맞는 템플릿을 선택한 후 Fig. 3 과 같이 Family 유형창에서 작성하고자 하는 Library 유형 을 선택한 후 매개변수와 그 값을 추가시킨다. 정렬치수를 이용하여 참조 선들을 앞서 추가시킨 매개변수와 일치시킨 후 이렇게 작성한 틀에 돌출, 혼합, 보이드양식 등을 사용 하여 사용자가 원하는 Solid 객체를 생성할 수 있다. 이렇 게 완성된 Family Library는 “*.rfa” 파일 형태로 저장되며, Family 편집기에서 프로젝트에 로드 버튼이나 프로젝트 작 성 창에서 Family 로드 버튼을 이용하여 프로젝트로 로드 할 수 있다.

이렇게 작성된 Family Library는 Revit 프로그램에서 사 용되며, 프로젝트로 로드된 Family Library객체는 사용자가 복사, 이동 등의 명령어를 통해 임의대로 배치 가능하며, 유 형 특성 창에서 앞서 작성한 매개변수의 값을 변경함으로써 그 형상 및 치수 또한 간편하게 조정할 수 있다.

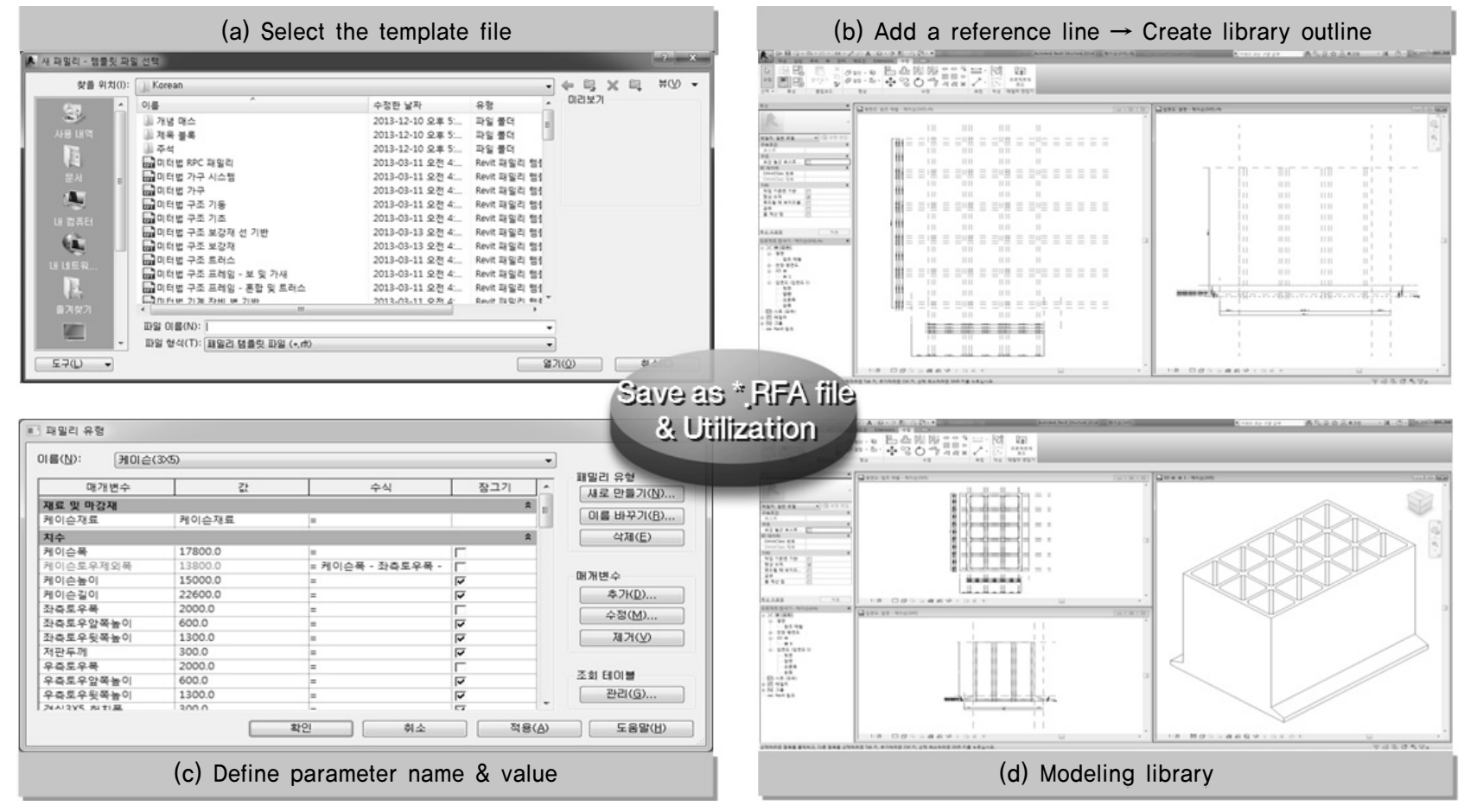

Fig. 3. Process of creating library using Revit program 


\section{3 준설매립전용 Library 구성}

준설토 투기장 설계 시 고려 가능한 상부구조 형식인 사 석경사제, 안벽 및 방파제 기초사석, 케이슨 구조 및 블록 구 조에 대하여 이상의 방법으로 작성된 상부구조물의 Library 는 Table 1 과 같다. 구조물 설계 시 법선 방향으로 연속성을 가지는 사석경사제, 안벽 및 방파제식 기초사석은 표준횡 단 Library 작성법을 이용하여 단면작성 시 고려 가능한 기 초사석, 피복석 및 상치콘크리트 등의 구조가 일체화되도록 계획하였으며 단면 폭, 높이, 두께, 기울기 등을 주요 변수 로 선정하여 단면 변화 시에도 가변성이 확보되도록 Library 를 구성하였다.

불연속적 개별 객체의 특성을 지닌 케이슨 및 블록구조 는 Family Library 작성법을 이용하여 작성하였다. 케이슨 구조는 그 형식이 매우 다양하기 때문에 격실 제원에 따라 단면 폭, 높이 및 길이 등을 주요 변수로 하여 단면의 가변 성을 확보하였으며, 블록 구조는 현재 항만 구조물 설계 시 많이 적용되고 있는 와록 블록, 이글루 블록에 대하여 단면 가변성이 확보되도록 Parametric Library를 작성하였다.

준설토 투기장의 하부 기초처리 공법으로 많은 적용사례 를 가지고 있는 굴착치환공법, 심층혼합처리공법, 다짐말뚝 공법 및 고압분사공법에 대하여 작성된 하부구조물 Library
는 Table 2 와 같다. 법선 방향으로 연속적으로 시공되는 굴 착치환공법은 굴착 폭, 기울기를 주요변수로 선정하여 표준 횡단 Library 작성법을 적용하였으며, 그 외의 지층 면에 수 직으로 시공되는 불연속적 개량공법은 Family Library 작성 법을 이용하여 작성하였다. 심층혼합처리공법은 각 개량체 의 직경, 길이, 개량체간 중첩 폭을 주요 변수로 하여 개량 체의 가변성을 확보하였다. 다짐말뚝 Library는 SCP 공법 및 $\mathrm{GCP}$ 공법을 대상으로 작성하였으며, 고압분사 공법은 RJP, FJS 등의 공법을 대상으로 상-하부의 직경이 다른 변 단면 개량체 조성 시에도 모델링이 용이하도록 단면 변수를 선정하였다.

\section{3. 전융 Library Browser 개발}

상기 작성된 준설매립 전용 Library의 통합관리가 용이하고 신규 Library 작성 시 업그레이드가 가능하며, BIM 기반 3D $\mathrm{CAD}$ 와의 연동이 가능하도록 준설매립 전용 Library Browser 를 개발하였다. Browser는 "Microsoft.NET Framework 4.0" 환경에서 "C\#" 언어를 이용하여 작성하였으며, "Autodesk ObjectARX" 패키지를 이용하여 Fig. 4의 단계로 Plug-In 하여 Autodesk사의 Civil 3D와의 연동이 가능하도록 개발하였다.

Table 1. Properties of Superstructures Library

\begin{tabular}{|c|c|c|c|c|c|}
\hline Division & Rubble mound & Quay wall Rubble mound & Breakwater Rubble mound & Caisson & Block \\
\hline \multicolumn{6}{|l|}{$\begin{array}{l}\text { Conceptual } \\
\text { diagram }\end{array}$} \\
\hline Using program & \multicolumn{3}{|c|}{ Subassembly composer } & \multicolumn{2}{|c|}{ Revit structure } \\
\hline $\begin{array}{l}\text { Leading } \\
\text { parameter }\end{array}$ & $\begin{array}{c}\text { Width, Slope, } \\
\text { Armor stone thickness }\end{array}$ & $\begin{array}{c}\text { Width, Slope, } \\
\text { Armor stone thickness }\end{array}$ & $\begin{array}{c}\text { Width, Slope, } \\
\text { Armor stone thickness }\end{array}$ & $\begin{array}{l}\text { Width, Length, Height, } \\
\text { Wall thickness }\end{array}$ & Weight \\
\hline $\begin{array}{c}\text { Composition of } \\
\text { Library }\end{array}$ & $\begin{array}{l}\text { Levee body }+ \\
\text { Armor stone }+ \\
\text { Cap concrete }\end{array}$ & $\begin{array}{c}\text { Rubble mound }+ \\
\text { Armor stone } \\
\text { (outside) }\end{array}$ & $\begin{array}{l}\text { Rubble mound + } \\
\text { Armor stone } \\
\text { (inside, outside) }\end{array}$ & $\begin{array}{c}\text { Chamber numbers, } \\
\text { Chamber }\end{array}$ & $\begin{array}{c}\text { Block shape, } \\
\text { Components } \\
\text { by weight }\end{array}$ \\
\hline
\end{tabular}

Table 2. Properties of Substructures Library

\begin{tabular}{c|c|c|c|c}
\hline Division & Excavation & $\begin{array}{c}\text { Deep mixing of } \\
\text { soil Stabilization }\end{array}$ & Compaction pile \\
$\begin{array}{c}\text { Conceptual } \\
\text { diagram }\end{array}$ & & & & \multicolumn{2}{|c}{ Revit structure } \\
\hline $\begin{array}{c}\text { Using program } \\
\text { parameter }\end{array}$ & Subassembly composer & Diameter, Length & Diameter, Length \\
\hline $\begin{array}{c}\text { Type of soil } \\
\text { improvement method }\end{array}$ & Excavation width, Slope & DCM, DWM & Sottom Diameter \& Length \\
\hline
\end{tabular}


Library Browser의 실행파일인 "BimlibBrowser.exe"(Fig. 4 (1) 참조)를 설치하면 Autodesk사의 Civil 3D와의 Plug-In 을 통해 메인메뉴 창에 "HangdoBIM" 리본이 자동생성된다 (Fig. 4 (2) 참조). 자동 생성된 리본은 "BIM Library, Slope Stability Analysis, Settlement Analysis, DCM Analysis"로 서브메뉴가 구성되어 있으나, 본 논문에서는 현재 개발 완 료된 "BIM Library"에 대해서만 설명하고 그 외에 Analysis 메뉴에 대해서는 향후 연구성과에 대해서 발표할 예정이다. BIM Library Browser의 메인 메뉴는 탐색기능, Civil 3D Library, Revit Library, Information 및 Help 창으로 구성되 며, 탐색기능을 통해 상기 2장에서 작성된 상부구조물 및 하부구조물에 대한 표준횡단 Library 및 Family Library를 로드할 수 있다. 이렇게 로드된 각각의 Library를 선택하면 속성정보 창에서 Library의 이미지 및 주요 변수를 확인할 수 있다.

또한 Civil 3D Library 및 Revit Library 메뉴는 각각의 프 로그램 실행기능, 기 작성된 Library를 프로젝트 파일에 로 드하는 내보내기 기능, 신규 Library 작성 기능으로 구성되 어 있어 프로젝트 수행 시 기존에 작성된 Library를 작업 창 에 간편하게 로드할 수 있고, 필요 시 수정 및 신규 제작이 가능하도록 개발하였다.

전용 Library Browser 활용 시 장점을 기존 방식과 비교 하여 Table 3에 기술하였다.

\section{Library의 설계적융 가이드라인}

일반적으로 토목 설계자는 프로젝트 수행 시 평면, 선형
을 계획하고 구조물의 표준단면도를 디자인하여 횡단 작성 및 물량산출 작업을 수행하게 된다. 이 작업은 인력과 시간 이 매우 많이 소요되며 평면 및 선형계획, 구조물 표준단면 이 바뀔 때마다 또다시 수행해야 하는 번거로움이 있다. 이 러한 반복 작업은 인력, 시간 및 비용을 지속적으로 소모시 킴으로써 프로젝트 효율성을 떨어뜨리고 설계비용을 증가 시키는 문제점을 유발한다. 이러한 문제점을 개선하기 위하 여 수많은 기술자들이 반복 작업을 줄일 수 있는 다양한 프 로그램을 개발하여 설계에 적용하고 있는 실정이며, 본 연 구에서도 준설매립분야의 프로젝트 효율성 증대를 위해 BIM 기반의 준설매립전용 Library Browser를 개발하였다. 개발 된 Browser를 통해 신규 Library의 작성 및 관리가 가능하 고 탑재된 준설매립전용 Library를 활용한 파라메트릭 모델 링으로 손쉽게 3 차원 구조물을 모델링할 수 있다.

본 절에서는 개발된 준설매립전용 Library 및 Browser를 이용하여 설계 효율성을 증가시킬 수 있는 가이드라인을 제 시하였다.

\section{1 적용 프로그램}

본 연구에서 개발된 Library 및 Browser의 설계적용 가이 드라인은 Civil 3D 및 Revit Structure로 구분하여 제시하였다.

Civil $3 \mathrm{D}$ 는 측량데이터를 이용한 $3 \mathrm{D}$ 지형 모델링, 평면 및 선형 계획, 횡단 및 토공 물량산출 자동화에 특화된 프 로그램이며, 개발된 Browser를 이용하여 사석경사제, 안벽 기초사석, 방파제 기초사석, 원지반 굴착치환을 3 차원으로 간편하게 모델링하고 그에 대한 토공 물량을 산출할 수 있다.

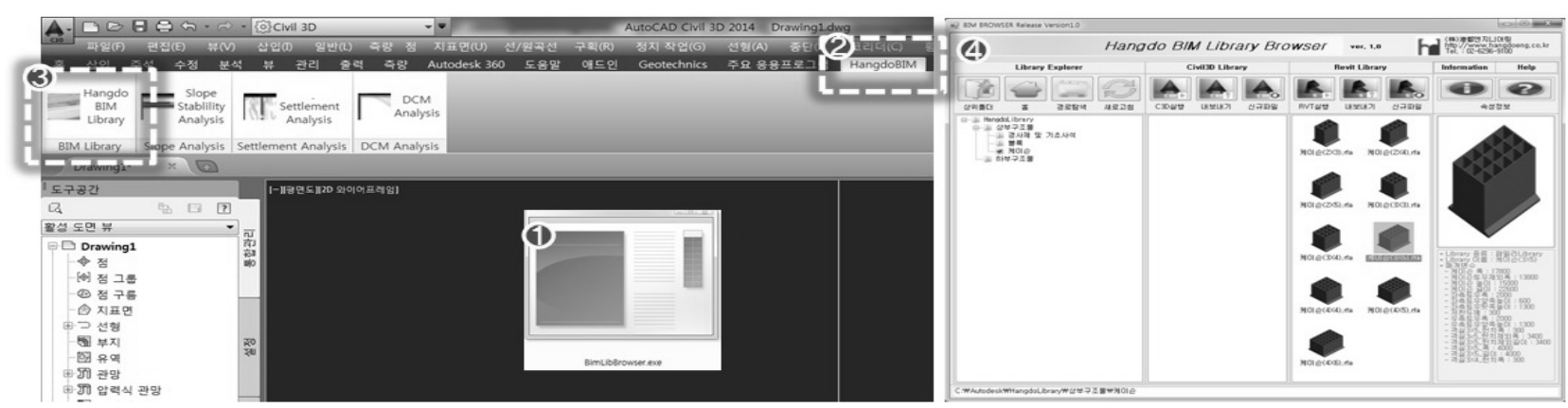

Fig. 4. Composition of Library Brower

Table 3. Library browser benefits

\begin{tabular}{c|l|l}
\hline Division & \multicolumn{1}{|c}{ Existing method } & \multicolumn{1}{c}{ Using library browser } \\
\hline \hline Feature & $\begin{array}{l}\text { Need to create Individual objects for each project } \\
\text { Difficult to integrated management of objects }\end{array}$ & $\begin{array}{l}\text { Easy to integrated management by browser } \\
\text { New libraries can be update }\end{array}$ \\
\hline Object generation & Using a separate program, Manual generation & Automatic generation by selecting an object from browser \\
\hline Usability & Complex, Need a simple repetitive works & Easy, Minimize the modeling time \\
\hline
\end{tabular}


Revit Structure는 교량, 터널, 옹벽, 가시설 등 일정한 모양 을 가지는 구조물 설계에 특화되어 있으며, 표준화된 Family Library로 3D 모델링 및 물량산출이 가능하다. Browser에는 안벽 및 방파제 케이슨, 항만 블록, 구조물 하부기초(DCM, $\mathrm{SCP}$, 고압분사 공법) Family Library를 포함하고 있다.

\section{2 개발 Browser를 이용한 3차원 모델링}

먼저 Civil 3D를 이용한 3차원 모델링 과정은 다음과 같 다. 실제 측량된 데이터(ASCII 파일) 및 고도 값이 포함된 지형도를 이용하여 지형정보가 반영된 3차원 표면을 모델 링하고, 평면 및 구조물 선형 계획을 작성한다. Browser에 탑재된 사석경사제 Library를 로드하여 표준횡단을 생성하 고 $3 \mathrm{D}$ 코리더를 모델링한다. $3 \mathrm{D}$ 코리더는 2 차원 단면인 표 준횡단 Library의 기준점 한 개와 선형 계획선을 연동하여 계획된 선형을 따라 2 차원 객체를 연속 생성하여 3 차원 형 상으로 만드는 방법으로써, 향후 선형계획 변경 시 평면에 서 선형선을 이동하면 표준횡단 Library와 자동으로 연동되 어 $3 \mathrm{D}$ 코리더를 작성하게 된다. 따라서 선형 계획 변경에 따른 반복 작업 시간이 크게 단축되며, 구조물 형상 변경 역 시 표준횡단 Library의 파라메트릭 값을 바꾸어 주면 자동 으로 연동되어 $3 \mathrm{D}$ 코리더를 생성하게 되며, 그 예는 Fig. 5 와 같다.

Revit Structure를 이용한 3차원 모델링 과정에 대한 설명 은 다음과 같다. Revit Structure는 표준화된 Family Library 를 이용하여 $3 \mathrm{D}$ 구조물 모델링이 가능하며, 선형에 따라 단 면 형상 및 제원이 변화하는 구조물 모델링엔 적합하지 않 다. 여기서는 $\mathrm{DCM}$ 하부기초 $3 \mathrm{D}$ 모델링에 대하여 설명하도 록 한다. DCM 배열은 상부 구조물 형식에 따라 달라지고, $\mathrm{DCM}$ 지지층 역시 불규칙하므로 그 부분에 대하여 중점적 으로 고려하여 모델링을 수행한다. 먼저 Library Browser에 서 DCM Family Library를 로드한 후 Array 명령어를 이용 하여 DCM 배열을 배치하고, 프로젝트로 내보내기 한다. 개 량 길이는 추후 상-하부를 지표면으로 잘라내기 할 것이므

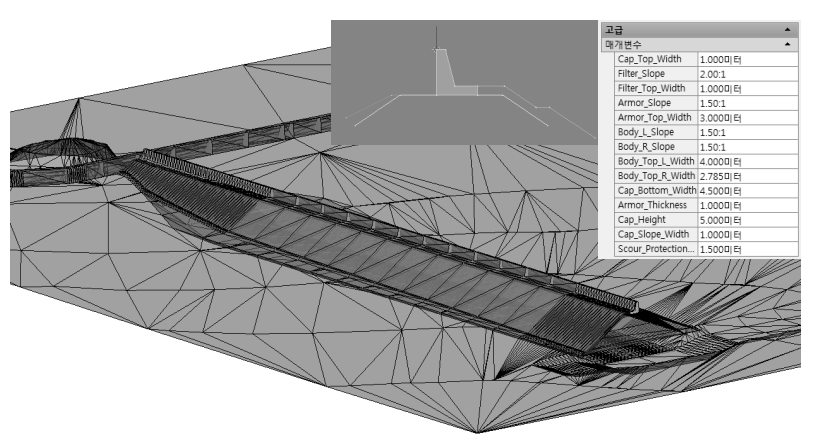

Fig. 5. Created revetment modeling using Civil 3D
로 실제 개량 길이보다 길게 작성한다. 다음으로 Civil $3 \mathrm{D}$ 에 서 3차원으로 작성된 $\mathrm{DCM}$ 개량 대상 원지반과 $\mathrm{DCM}$ 지지 층을 객체로 추출하여 $3 \mathrm{D}$ Solid로 만들고, $\mathrm{dwg}$ 파일로 저장 한다. Revit의 내부편집 매스에서 CAD 가져오기를 이용하 여 앞서 저장한 $\mathrm{dwg}$ 파일을 불러들인 뒤 내부편집 매스를 완료하고 프로젝트 창에서 수정 탭의 절단을 이용하여 DCM 객체를 지표면 Solid로 잘라내기 하면 Fig. 6과 같이 DCM 객체의 상·하부가 불균일한 지표면과 일치되는 모델링이 완료된다.

\subsection{BIM 기반의 물량산출 자동화}

Civil 3D를 이용한 물량산출 자동화 과정은 다음과 같다. 물 량산출을 원하는 구간에 대한 횡단면을 계획하고, 지표면과 구조물의 경계면을 설정한다. 횡단면을 작성하면 자동으로 각 단면에 해당하는 지형 및 구조물 형상과 물량 산출표가 작성되며, 물량산출 역시 $3 \mathrm{D}$ 코리더 형상과 자동 연동되므 로 선형 계획 및 구조물 단면 변경 시 자동으로 물량이 변경 되어 산출된다. 자동 물량산출 방법은 횡단면 상의 구조물 및 토공 면적과 횡단간의 거리를 이용하여 산정되며, 산정 예는 Fig. 7과 같다.

다음은 Revit Structure를 이용한 물량산출 과정에 대한 설명이다. 기존의 항만설계에서 $\mathrm{DCM}$ 개량공법의 물량산 출 시 개량구역을 다수의 구역으로 나누는 이유는 지반의

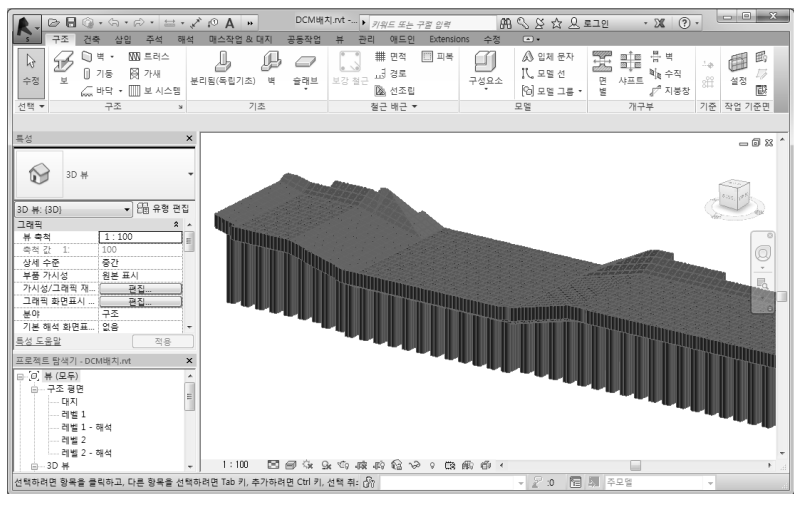

Fig. 6. Created DCM modeling using Revit Structure

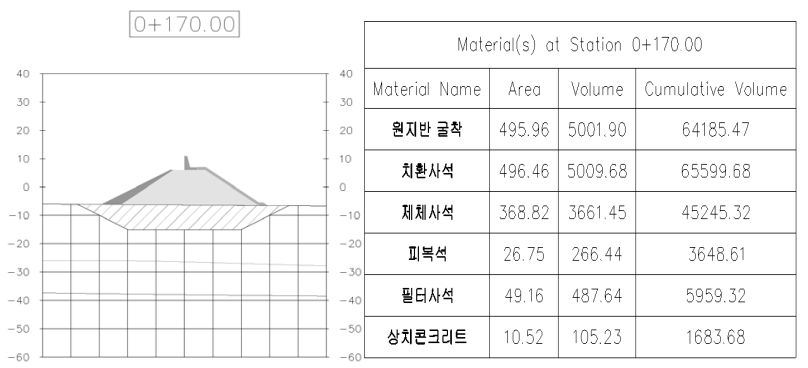

Fig. 7. Calculated revetment quantity using Civil 3D 


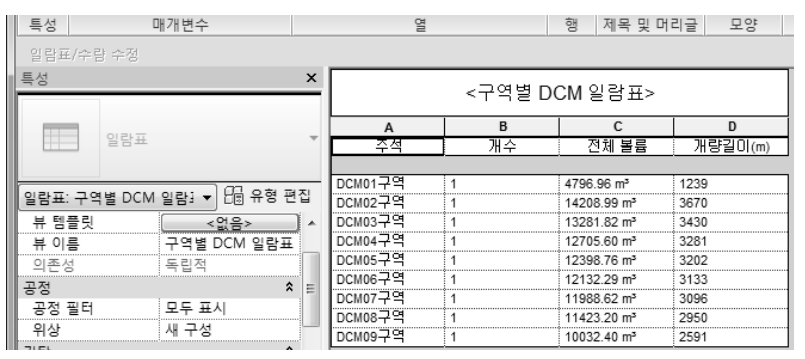

Fig. 8. Calculated DCM quantity using Revit Structure

불균일성에 기인한다. $\mathrm{DCM}$ 장주의 경우 하부지지층까지 개량하여야 하나 그 지지층이 불균일하여 수많은 객체의 길이를 일일이 산정할 수 없기 때문에 다수의 구역에서 지 지층 심도 콘터를 이용하여 산정한 구역별 대표 길이와 개 량본수를 이용하여 물량을 산출함으로써 그 오차를 조금이 나마 줄일 수 있다.

하지만 Revit 프로그램 내의 일람표/수량작성 기능을 이 용하면 다수의 구역으로 나눌 필요 없이 개량 길이, 체적 등 에 대한 정확한 자동물량산출이 가능하다. Fig. 6 과 같이 DCM 배치가 모두 완료되면 물량산출을 하고자 하는 Solid 객체를 선택한 후 유형특성 창의 ID 데이터에서 주석항목 에 원하는 주석을 입력한다. 이후 일람표/수량의 필드, 필터, 정렬/그룹화 등을 이용하여 일람표를 작성한다. 이를 이용 하면 전체적인 체적 및 개량 길이 등에 대한 수량산출은 물 론 Fig. 8과 같이 구역별 수량산출도 가능하다.

\section{5. 결 론}

본 연구에서는 준설매립분야의 BIM 기반 구축을 위하여 준설토 투기장 설계 시 필요한 상부 및 하부 구조물을 대상 으로 BIM Library를 작성하였으며, 이렇게 작성된 Library 의 통합관리가 용이하도록 준설매립 전용 Library Browser 를 개발하였다.

(1) 현장조건별 비정형화된 구조물을 사용하는 토목구조 물의 특성을 고려하여 주요 단면의 제원을 매개변수로 하여 프로젝트 조건별 단면의 가변성을 확보할 수 있 도록 기초사석, 사석경사제, 케이슨 및 블록 등의 상부 구조물과 심층혼합처리, 다짐말뚝, 고압분사 및 준설 치환 등의 하부지반개량 공법에 대한 준설매립 전용
Parametric Library를 개발하였다.

(2) 본 연구에서 개발된 Parametric Library를 준설매립전용 Library Browser를 이용하여 통합 관리하고 BIM 기반 의 Civil 3D 프로그램과 연동함으로써 준설매립 분야의 $\mathrm{BIM}$ 활용 효율성이 더욱 증대될 것으로 판단된다.

(3) Parametric Library의 설계적용 가이드라인을 통해 단순 작업의 최소화, 모델링 시간단축 및 정확한 물량산출 등 이 가능함으로써 설계효율 향상 및 정확성 개선에 기여 할 것으로 사료된다.

(4) 본 연구의 준설매립전용 Library Browser 개발과 연계 하여 향후 BIM 기반의 Analysis Browser를 개발함으로 써 준설매립분야의 일원화된 모델링 및 해석 시스템의 구축이 가능할 것으로 사료된다.

\section{감사의 클}

본 연구는 국토교통과학기술진흥원의 “환경친화적 준설 토 확보, 매립 및 운송거리 $30 \mathrm{~km}$ 이상급 이송기술개발(12 기술혁신E12)"의 연구성과의 일부임을 밝히며, 재정지원에 감사드립니다.

\section{References}

1. Han, J. H. and Nam, S. H. (2011), A study on the automated estimating system using BIM based library, Journal of KBIM, Vol. 1, No. 2, pp. 12 18 (in Korean).

2. Han, J. H., Nam, S. H., Kim, S. H. and Kim, Y. H. (2011), A study on the implementation of structural module library for the application of BIM technology, Proceeding of the Computational Structural Engineering Institute Conference, pp. 107 110 (in Korean).

3. Hong, S. U., Cho, Y. S., Lee, J. H. and Hong, S. C. (2011), The study on development of automatic reinforcement placing system of columns for RC structures based on parametric technology, Journal of Architectural Institute of Korea, Vol. 27, No. 1, pp. 11 18 (in Korean).

4. Jun, K. H. and Yun, S. H. (2011), Developing construction object library for BIM based building construction planning, Journal of Architectural Institute of Korea, Vol. 27, No. 9, pp. 143 151 (in Korean).

5. Kang, L. S., Kim, S. G., Kim, H. S., Moon, H. S. (2011), BIM application for civil engineering project in planning and design phases, Journal of KBIM, Vol. 1, No. 1, pp. 26 31 (in Korean). 